\title{
In vitro and in vivo herpetic vector-mediated gene transfer in the pituitary gland: impact on hormone secretion
}

\author{
Federico Bolognani, César Albariño ${ }^{1}$, Victor Romanowski ${ }^{1,2}$, Néstor G Carri ${ }^{3}$ and Rodolfo G Goya \\ Institute for Biochemical Research of La Plata (INIBIOLP) - Histology 'B', Faculty of Medicine, ${ }^{1}$ Institute of Biochemistry and Molecular Biology, \\ Faculty of Exact Sciences, National University of La Plata, ${ }^{2}$ University of Quilmes, Bernal and ${ }^{3}$ Multidisciplinary Institute of Cell Biology, Argentina \\ (Correspondence should be addressed to R G Goya, INIBIOLP, Faculty of Medicine, UNLP, CC 4551900 La Plata, Argentina; \\ Email: goya@isis.unlp.edu.ar)
}

\begin{abstract}
Objective: Herpes simplex virus type 1 (HSV-1)-derived vectors are known to be effective tools to deliver transgenes into normal and neoplastic anterior pituitary (AP) cells in vitro. Our objective was to assess the in vitro and in vivo effects of $t s \mathrm{~K} / \beta$-gal, a temperature-sensitive HSV-1-derived vector harbouring the E. coli $\beta$-galactosidase gene, on AP hormone secretion as well as on transgene expression in rat AP tumours (hyperplastic prolactinomas).

Design: The impact of vector infection on prolactin (PRL) and GH release was determined in vitro in normal and hyperplastic (lactotrophic) dispersed AP cells exposed for $24 \mathrm{~h}$ to $t s \mathrm{~K} / \beta$-gal as well as in vivo in ectopic AP grafts. In some oestrogen-induced prolactinoma-carrying rats, vector suspension was stereotaxically injected into the glands to assess transgene expression in vivo.

Methods: GH and PRL release was measured by specific RIAs. In vivo transgene expression was assessed by immunohistochemistry for $\beta$-galactosidase and enzymohistochemistry (5-bromo-4chloro-3-indolyl- $\beta$-D-galactopyranoside). Ectopic pituitary grafts and stereotaxic surgery were performed following standard procedures.

Results: At a multiplicity of infection of 0.5 , the vector induced a 30 and $22 \%$ fall in PRL and GH release respectively in normal AP cells, whereas the corresponding hormone release inhibition for hyperplastic AP cells was 41 and 33\% for PRL and GH respectively. In ectopic pituitary grafts, the effect of vector infection on hormone secretion was assessed by measuring serum PRL levels in the host rats every 5 days for 4 weeks post-grafting. In the pituitary-grafted rats that received the viral vector, serum PRL failed to increase to the levels achieved in control-grafted animals. Finally, pituitary tumours stereotaxically injected with $t s K / \beta$-gal showed widespread expression of the $\beta$-galactosidase transgene around the injection areas.

Conclusions: The results reported here have implications for basic studies using gene transfer to pituitary gland as well as potential gene therapy approaches to pituitary diseases.
\end{abstract}

European Journal of Endocrinology 145 497-503

\section{Introduction}

Gene transfer methodologies have become powerful tools for basic research studies and for therapeutic purposes. In recent years, we and others have provided evidence suggesting that viral vectors constitute suitable tools for the delivery of genes to neuroendocrine cells (1). Adenoviral and herpetic vectors were successfully used to transfer different genes into normal and neoplastic anterior pituitary (AP) cells in culture $(2-8)$. Moreover, adenoviral vectors have been used to transfer in vivo the herpes simplex virus type 1 (HSV-1)thymidine kinase (TK) suicide gene to somatomammotrophic tumour cells $\left(\mathrm{GH}_{3}\right)$ grafted into nude mice as well as to oestrogen-induced rat lactotrophic tumours $(6-8)$.
HSV-1-derived vectors have been used less frequently than adenoviral vectors for gene transfer to the neuroendocrine system. The only herpetic vectors so far used in this system are those derived from tsK, a temperature-sensitive mutant of HSV-1. The genome of $t s \mathrm{~K}$ vectors has a mutation in the ICP4 gene, the major transcriptional activator of HSV-1, which yields an inactive ICP4 product at or above $37{ }^{\circ} \mathrm{C}$, thus precluding replication at these temperatures. As protein ICP4 is fully active at $31{ }^{\circ} \mathrm{C}$, tsK mutants are replication competent at this permissive temperature $(9,10)$. Using the $t s \mathrm{~K} / \beta$-gal vector, it has been previously shown that this kind of vector is capable of transducing pituitary-derived cell lines (AtT20 and $\mathrm{GH}_{3}$ ) as well as normal AP cells in vitro (3). Recently, another tsK-derived vector, tsK/CRH10, expressing the 
rat corticotrophin-releasing hormone precursor (preproCRH (ppCRH)) was constructed. It was demonstrated that neural and glial, but not epithelial, cell lines infected with $t s K / C R H 10$ correctly post-translationally process ppCRH and secrete biologically active CRH (11).

In order to assess the suitability of $t s \mathrm{~K}$ vectors for functional studies and therapeutic approaches in the pituitary gland, we studied the effects of a tsK vector carrying the $E$. coli $\beta$-galactosidase gene, on prolactin $(\mathrm{PRL})$ and growth hormone $(\mathrm{GH})$ secretion in normal and hyperplastic rat AP cells in vitro and in oestrogeninduced AP rat prolactinomas in vivo.

\section{Materials and methods}

\section{HSV-1-derived recombinant viral vector}

The virus used in these studies, $t$ sK/ $\beta$-gal, was kindly provided by Dr Christopher M Preston, MRC Virology Unit, University of Glasgow, UK. This temperaturesensitive mutant of HSV-1 (strain 17) contains the E. coli lacZ open reading frame cloned into the TK locus under the control of the HSV immediate-early 3 (IE3) gene promoter (Fig. 1). The vector was propagated by infecting baby hamster kidney (BHK21) cells growing at $31{ }^{\circ} \mathrm{C}$. Cells were grown in minimum essential medium (Gibco, Buenos Aires, Argentina) supplemented with $10 \%$ foetal calf serum (Bioser, Buenos Aires, Argentina), L-glutamine $(0.3 \mathrm{~g} / \mathrm{l})$, and nonessential amino acids (Sigma Chemical Co., St Louis, MO, USA). Cells were harvested when a cytopathic effect was evident and the virus purified and titrated according to standard procedures (10). Virus titre was $5.0 \times 10^{8}$ plaque forming units $(\mathrm{pfu}) / \mathrm{ml}$. In order to assay for the presence of wild-type revertants, serial dilutions of supernatants from tsK/ $\beta$-gal-infected BHK21 cells grown at $37^{\circ} \mathrm{C}$ were added to BHK21 cells, which were subsequently grown at $31{ }^{\circ} \mathrm{C}$ for 7 days. The ratio of wild-type revertants calculated from this test was found to be lower than $1: 10^{5}$ pfu.

\section{Animals and prolactinoma induction}

Adult (5- to 7-month-old) Sprague-Dawley rats, raised in our colony at INIBIOLP, were kept under a $12 \mathrm{~h}$ light:12 h darkness cycle with water and food freely available. All experiments on animals were done in conformity with the Guidelines on the Handling and Training of Laboratory Animals published by the Universities Federation for Animal Welfare (12). Hyperplastic APs, also referred to here as pituitary tumours, were induced in adult females by weekly i.m. injections of $40 \mu \mathrm{g} 17 \beta$-oestradiol valerate (Sigma) in $0.2 \mathrm{ml}$ sunflower oil, carried out for 8 weeks.

\section{In vitro experiments}

In each experiment, an average of eight APs were cut with a razor blade into eight to ten pieces each, and placed in a Petri dish where they were washed twice with secretion medium (SM: Earle's balanced salt solution containing $1 \mathrm{~g} / \mathrm{l}$ glucose, $1 \mathrm{~g} / \mathrm{l} \mathrm{NaHCO}_{3}$, $0.5 \%$ BSA and $30 \mathrm{mg} / \mathrm{ml}$ ascorbic acid, $\mathrm{pH} 7.4$ (Sigma)). The pieces were transferred to a plastic tube with $10 \mathrm{ml} \mathrm{SM}$ containing $32 \mathrm{mg}$ collagenase type IV and $4 \mathrm{mg}$ DNAse type I 4 (Sigma). After $1 \mathrm{~h}$ incubation at $37^{\circ} \mathrm{C}$ under constant shaking, the resulting cell suspension was gently dispersed by pipetting, in order to eliminate cell clusters, and finally centrifuged at $500 \boldsymbol{g}$ for $10 \mathrm{~min}$. The supernatant was discarded and cells were resuspended in culture medium (SM plus $10 \%$ horse serum). Cell viability, evaluated by the Trypan blue exclusion test, was consistently higher than $90 \%$. Cells were finally seeded in plastic tubes at a concentration of $5 \times 10^{5} \mathrm{cells} / \mathrm{ml}$ and infected with tsK/ $\beta$-gal at the indicated multiplicity of infection (MOI). After $24 \mathrm{~h}$ incubation at $37^{\circ} \mathrm{C}$, tubes were centrifuged, the corresponding pellets resuspended in $1 \mathrm{ml} \mathrm{SM}$ and incubated for $1 \mathrm{~h}$ at $37^{\circ} \mathrm{C}$. Tubes were centrifuged again and the supernatants collected and stored at $-20{ }^{\circ} \mathrm{C}$ for hormone determinations.

\section{In vivo experiments}

Recipient female rats were placed under ketamine hydrochloride anaesthesia $(40 \mathrm{mg} / \mathrm{kg}$, i.p. $)$ and their left kidney surgically exposed by a back incision. Then, an AP, freshly removed from a highly inbred female donor, was injected ex vivo with $1 \mu$ l of either saline (controls) or viral suspension containing $5 \times 10^{5} \mathrm{pfu}$ tsK/ $\beta$-gal, and immediately placed under the kidney

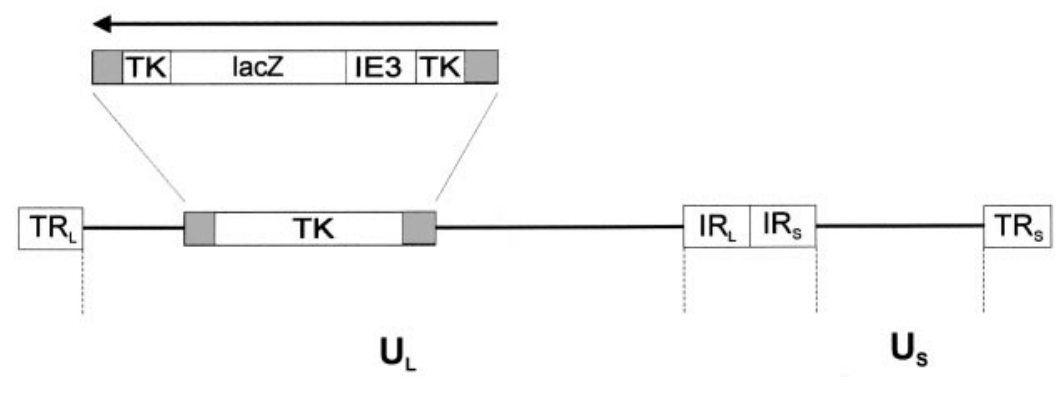

Figure 1 Structure of the $t s K / \beta$-gal genome, which is composed of unique long $\left(U_{\mathrm{L}}\right)$ and unique short $\left(U_{S}\right)$ regions, flanked by inverted repeats $\left(T R_{L}, I R_{L}, I R_{S}\right.$ and $\left.T R_{S}\right)$. The $\beta$-galactosidase gene is inserted into the TK locus under the control of an IE3 promoter. The arrow indicates the direction of transcription. From (15), with some modifications. 
capsule of the recipient. The kidney was then replaced within the abdominal cavity, muscle and skin were sutured and the animals were allowed to recover from anaesthesia in individual cages. Usually, rats recovered fully from surgery within a few hours.

In the grafted animals, blood samples were taken under light ether anaesthesia from the tail veins every 5 days beginning on the day of surgery. Serum was separated and kept at $-20{ }^{\circ} \mathrm{C}$ until hormone assays.

Some rats bearing oestrogen-induced prolactinomas received in each AP lobe a $1 \mu$ intrapituitary injection containing $5 \times 10^{5} \mathrm{pfu} t \mathrm{sK} / \beta$-gal. For this purpose, rats were anaesthetised with an i.m. injection of ketamine hydrochloride $(40 \mathrm{mg} / \mathrm{kg})$ plus xylazine $(8 \mathrm{mg} / \mathrm{kg})$ and placed into a stereotaxic frame. To access the AP lobes, the tip of a 26 gauge needle fitted to a $10 \mu$ l syringe was stereotaxically brought to the following coordinates relative to the bregma: $5.6 \mathrm{~mm}$ posterior, $10.4 \mathrm{~mm}$ ventral and $1 \mathrm{~mm}$ right and left, for each AP lobe (13). At the appropriate times, animals were killed for immunohistochemical assessment of transgene expression in the AP.

\section{Hormone assays}

Rat PRL and GH were assayed by specific RIAs using materials provided by Dr A F Parlow, Pituitary Hormones and Antisera Center, Harbor-UCLA Medical Center, Torrance, CA, USA. Values for PRL and GH are expressed in terms of the US National Hormone and Pituitary Program rPRL-RP-3 and rGH-RP-2 respectively.

\section{Immunohistochemistry and enzymohistochemistry}

For pituitary immunohistochemistry, glands stereotaxically injected with tsK/ $\beta$-gal were fixed in Bouin's fluid and embedded in paraffin. Serial $4 \mu \mathrm{m}$ sections were obtained at different levels of the blocks following a ventral to dorsal sequence. Sections were incubated overnight at $4{ }^{\circ} \mathrm{C}$ with a $1 / 800$ dilution of a rabbit anti$\beta$-galactosidase serum generated by us or with rabbit antiserum against rPRL (code: PRL-9), obtained from Dr A F Parlow, used at 1/100 dilution. After washing, sections were processed with the Vectastain ABC kit (Vector Laboratories, Burlingame, CA, USA), using diaminobenzidine as chromogen (Sigma).

In some experiments, stereotaxically injected pituitary tumours were submitted to enzymohistochemistry for $\beta$-galactosidase activity. Injected animals were killed 2 days after surgery, and tumours fixed for $1 \mathrm{~h}$ in $4 \%$ paraformaldehyde-PBS at $\mathrm{pH}$ 7.2. Glands were incubated overnight in 0.01\% 5-bromo-4-chloro-3-indolyl$\beta$-D-galactopyranoside (X-gal; Calbiochem, San Diego CA, USA) solution and further fixed for $3 \mathrm{~h}$. Specimens were then embedded in paraffin and processed for histology as indicated above.

\section{Statistics}

The level of significance of differences between released hormone concentrations in the in vitro experiments was assessed by one-way ANOVA. When appropriate, ANOVAs were followed by the Tukey's multiple range test to assess the significance of differences between means. A $P$ value lower than 0.05 was considered significant in all cases. The in vivo data were analysed by a split-plot design using the general linear model procedure employing the SAS software package (version 6.12; SAS Institute, Madison, WI, USA).
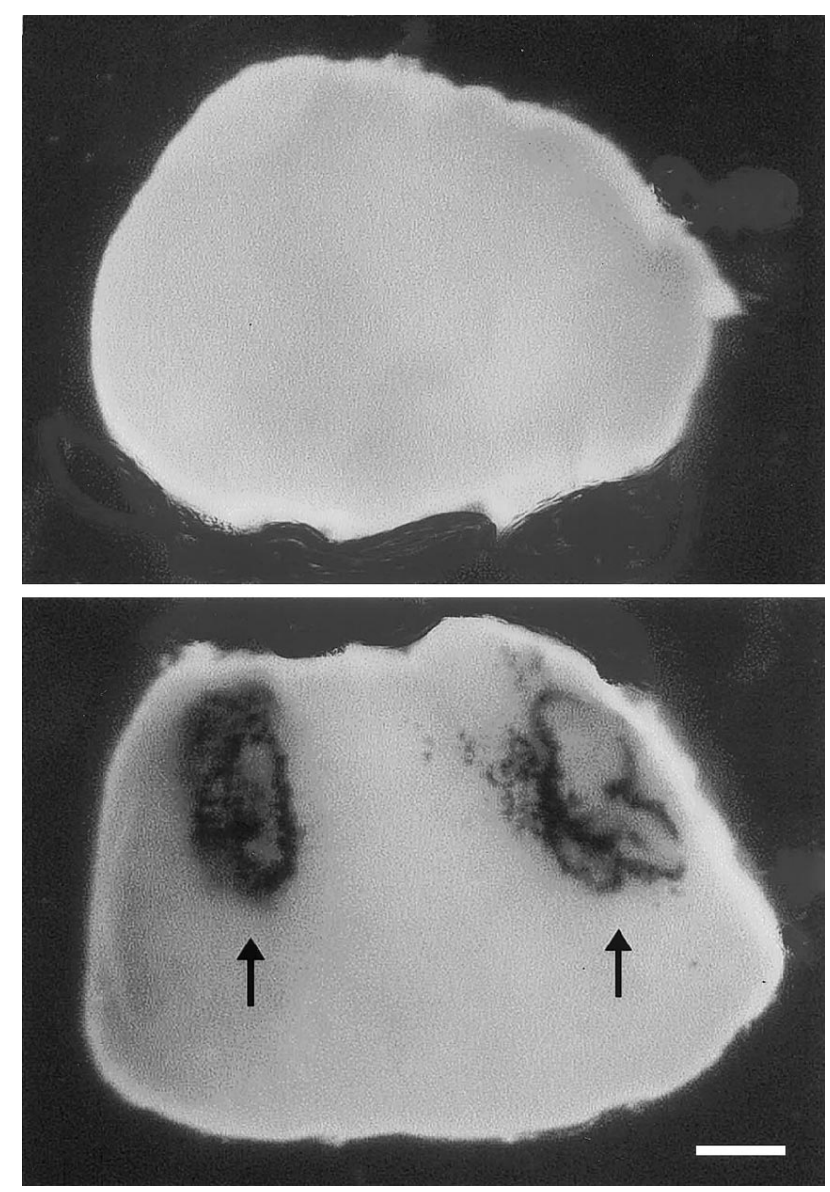

Figure 2 Macroscopic view of oestrogen-induced rat prolactinomas stereotaxically injected ( $1 \mu$ l, bilaterally) with either saline (upper panel) or $t s \mathrm{~K} / \beta$-gal (lower panel). Two days after injection, glands were removed, fixed for $1 \mathrm{~h}$ and submitted to $\mathrm{X}$-gal

enzymohistochemistry. After blue colour development, glands were further fixed overnight. Glands are shown from the ventral side. Arrows indicate injection sites. For further details, see the text. Scale bar on the lower right corresponds to $0.5 \mathrm{~mm}$. 


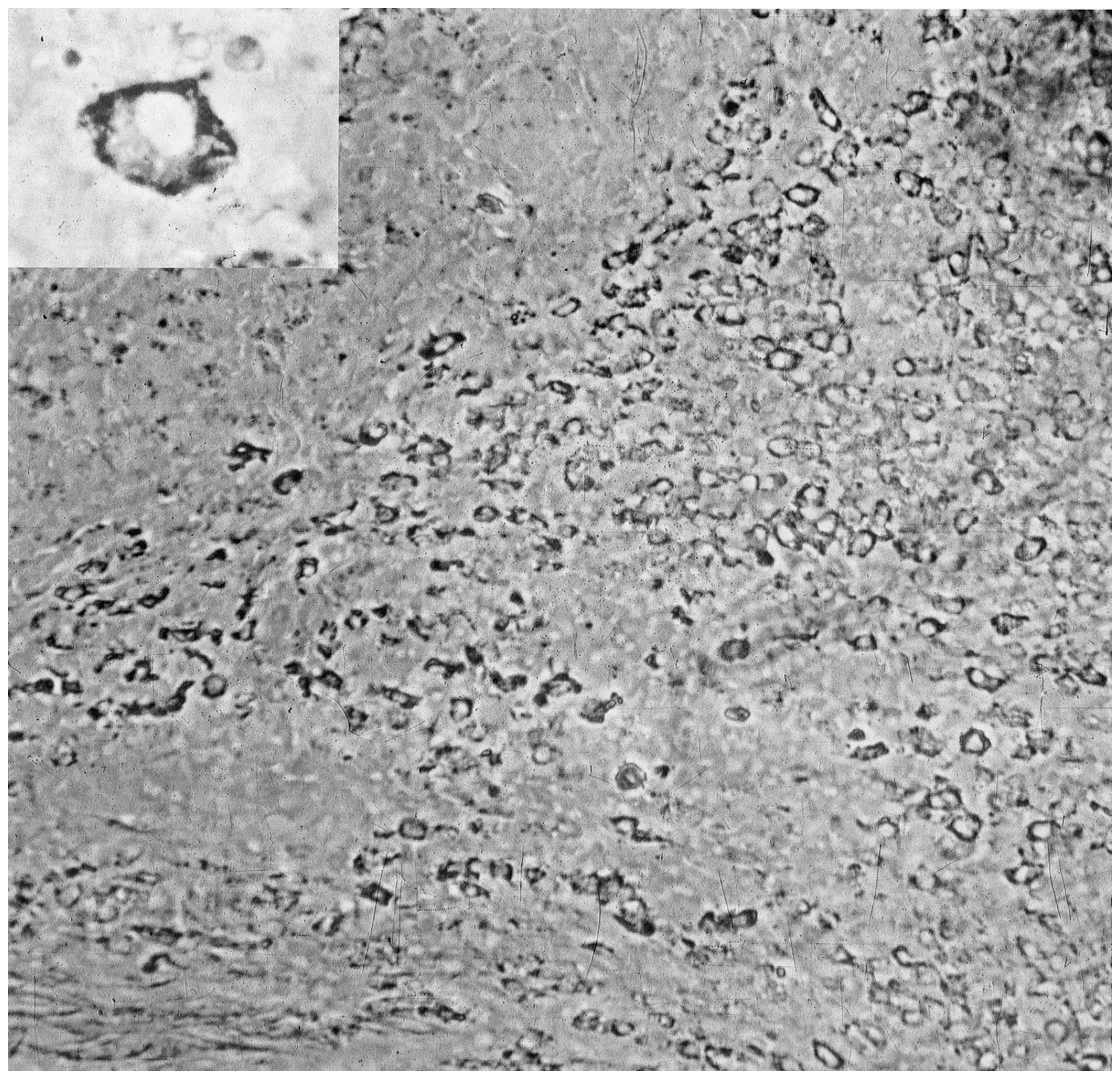

Figure 3 Oestrogen-induced rat pituitary prolactinoma infected with $t s \mathrm{~K} / \beta$-gal and immunostained for $\beta$-galactosidase. The vector was stereotaxically injected in $1 \mu$ l viral suspension $\left(5 \times 10^{5} \mathrm{pfu}\right)$ per lobe in the pituitary gland, and 3 days later transgene expression was assessed immunohistochemically. Immunostained cells show morphological features compatible with different endocrine cell populations (objective $\times 16$ ). Inset is a view of the same section at a higher magnification (objective $\times 40$ ).

\section{Results}

\section{Pituitary transgene expression in vivo}

In previous studies, it was shown that $t s K / \beta$-gal efficiently transduced all endocrine AP cells in vitro, including lactotrophic and somatotrophic cells (3). Here, we expanded these studies by assessing transgene expression in the adenohypophysis in vivo. As expected, oestrogen-induced pituitary adenomas showed a high lactotrophic cell hyperplasia and generated a marked hyperprolactinaemia as well as a moderate hypersomatotrophinaemia (data not shown). Pituitary adenomas stereotaxically injected with $t s \mathrm{~K} / \beta$-gal showed an intense expression of the $\beta$-galactosidase transgene around the injection areas (Fig. 2). The infected areas probably correspond to the diffusion areas of viral suspension. Immunohistochemical analysis of these areas revealed a high level of transduction in vivo (Fig. 3). 

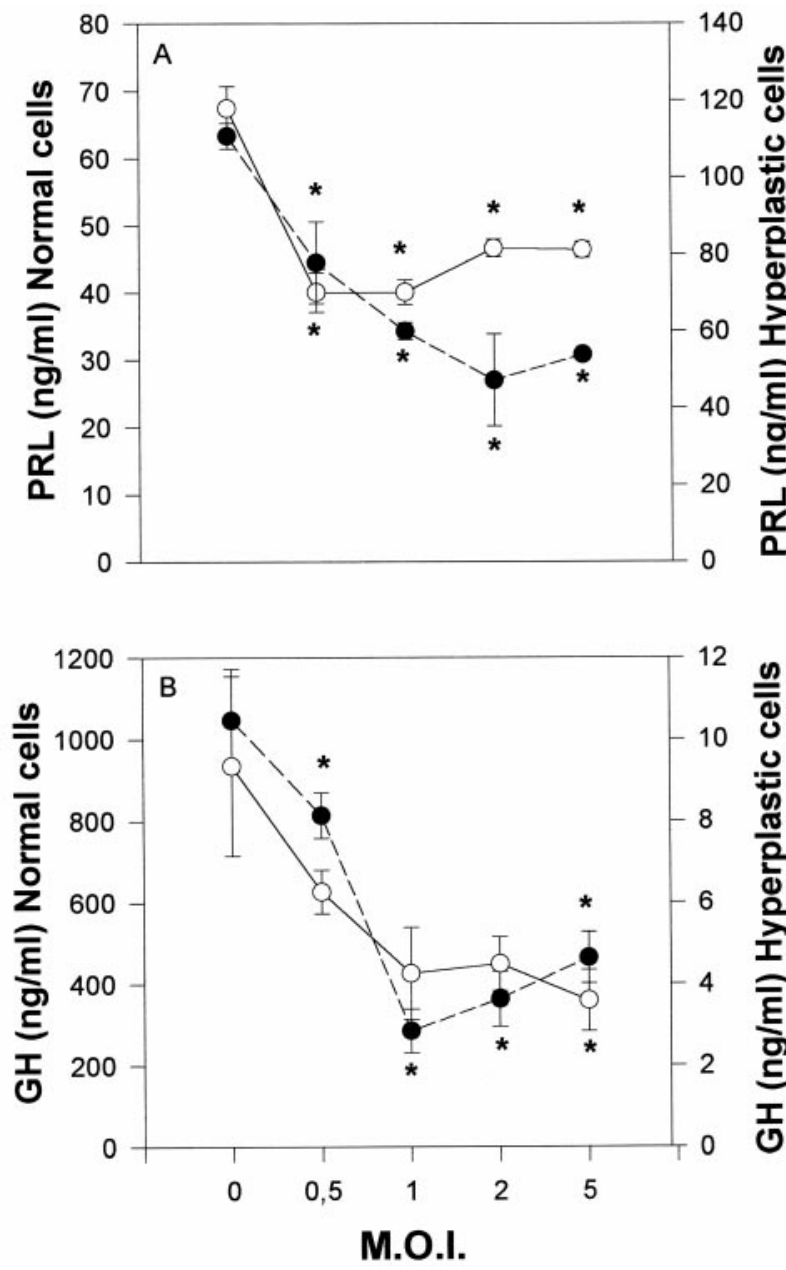

Figure 4 Secretion of PRL (A) and GH (B) by AP cells from normal $(\bullet)$ and oestrogen-treated $(O)$ rats infected with $t s \mathrm{~K} / \beta$-gal at increasing $\mathrm{MOI}$ values. Results are means \pm S.E.M. ${ }^{*} P<0.05$ differences from controls $(\mathrm{MOI}=0)$ for each cell culture type. Also notice that left (normal cells) and right (hyperplastic cells) scales on $y$-axes are different; $n=4$ for all groups. The figure shows one representative experiment from a total of six.

\section{Impact of vector infection on GH and PRL secretion in vitro}

Normal and hyperplastic AP cells exposed to tsK/ $\beta$-gal showed a significant reduction in both PRL and GH release (Fig. 4). At an MOI of $0.5 \mathrm{pfu} /$ cell, the vector induced a 30 and $22 \%$ fall in PRL and GH release respectively in normal AP cells, whereas the corresponding hormone release inhibition for hyperplastic AP cells was 41 and 33\% for PRL and GH respectively. Thus, hyperplastic cells appeared to be more susceptible than normal AP cells to the inhibitory action of tsK/ $\beta$-gal. The inhibitory action of the vector on normal cells was maximal at an MOI of 2 and $1 \mathrm{pfu} / \mathrm{cell}$ for PRL and GH release respectively, whereas in hyperplastic cells maximal inhibition was achieved at

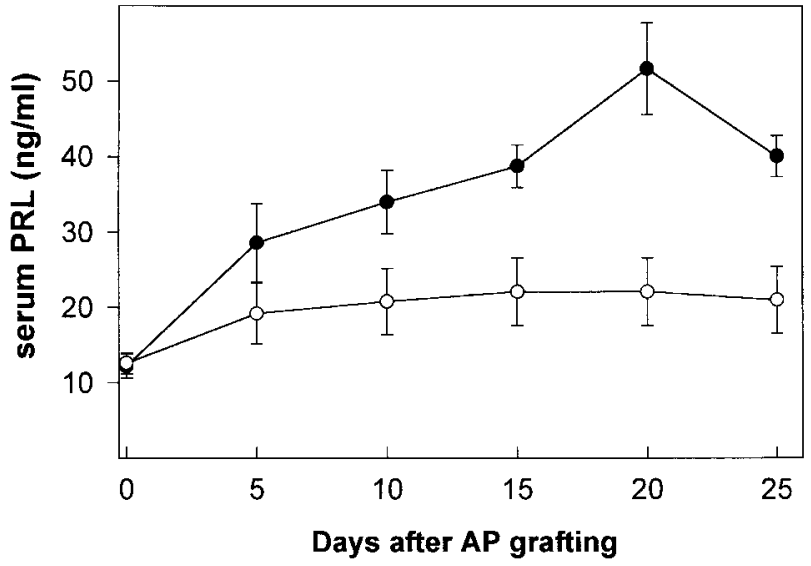

Figure 5 Serum PRL levels in rats carrying a pituitary graft under the kidney capsule. One group was injected with $t s \mathrm{~K} / \beta$-gal $(O)$ and the other with vehicle $(\bullet)$. Results are expressed as means \pm S.E.M., $n=10$ for both groups.

MOI $=0.5 \mathrm{pfu} / \mathrm{cell}$ for PRL release and MOI $=1 \mathrm{pfu} /$ cell for GH. In general, MOI values greater than $1 \mathrm{pfu} /$ cell did not bring about further reductions in hormone release.

\section{Effect of tsK/ß-gal infection of pituitary grafts on host serum PRL}

Initial trials showed that stereotaxic injections into the pituitary sometimes caused significant haemorrhages, which most likely were due to mechanical damage to the abundant vessels that surround this gland. Since these haemorrhages plus eventual mechanical damage to hypothalamic structures could randomly affect pituitary hormone secretion in both virus- and salineinjected animals, we chose to study the functional impact of vector infection in ectopic AP grafts. The $e x$ vivo vector delivery approach used in this study permitted a better control of random artefacts, thus leading to more reproducible results.

Pituitaries grafted under the kidney capsule survived satisfactorily in most cases, showing a significant revascularisation and no signs of host-versus-graft rejection for at least 5 weeks (maximal length of time of our studies). This apparently substantial degree of histocompatibility is likely to arise from the high inbreeding of our animals. As expected, immunohistochemical assessment of the grafts at different times post-surgery revealed a progressive hyperplasia of the lactotrophic cell population (data not shown) which was paralleled by a progressive hyperprolactinaemia that reached its maximum around the third week postgrafting, beginning to decline gradually afterwards (Fig. 5). In the grafted rats that received the viral vector, serum PRL failed to increase to the levels achieved in the control-grafted animals (Fig. 4). 


\section{Discussion}

HSV-1 is an enveloped double-stranded DNA virus with a genome of approximately $150 \mathrm{~kb}$, encoding at least 80 genes (14). This virus is able to infect cells lytically or establish latency, especially in some neurons. HSV-1derived vectors have several advantages for gene therapy, which include the availability of several replication-defective mutants and the ability of the virus to establish latency in some neurons, as well as its large capacity for harbouring transgenes (up to $30 \mathrm{~kb}$ ). Although HSV-1-derived vectors have been extensively used for gene transfer in the central nervous system (15), it is only in the last few years that they have been shown to possess the capability to transduce endocrine cells. Thus, it was reported that apoptosis could be prevented in pancreatic $\beta$-cells by transducing them with an HSV-1 amplicon vector carrying the bcl-2 gene, a result that points to the potential of this vector for the prevention of type 1 diabetes mellitus $(16,17)$. As indicated above, tsK vectors have been also shown to transduce normal and neoplastic AP cells efficiently in vitro (3). Our results reveal that infection of AP cells with an HSV-1-derived vector induces a decrease in PRL and GH secretion in vitro and PRL in vivo. In addition, in vitro studies with $t s K / \beta$-gal showed that this vector inhibits the regulated secretion of adrenocorticotrophic hormone in cultured rat AP cells (18), which is in line with the results reported here. The mechanisms involved remain unclear, but two properties of HSV-1 may explain our results. First, this type of vector is known to be highly cytotoxic in other cell types, although this effect appears at higher MOI values and longer post-infection times than in the experiments reported here (9). On the other hand, the HSV-1 virion host shutoff protein encoded by the UL41 gene reduces non-specifically cell mRNA half-life $(19,20)$. Furthermore, it has been demonstrated that the infection with tsK-derived vectors inhibits protein synthesis in primary cultures of neurons and glia (9). If these mechanisms are involved in the inhibitory action of tsK vector on AP hormone secretion remains to be determined. The possibility that a diffusible hormone release-inhibiting factor(s) is produced by the transduced cells should also be considered. In any case, the present study extends the initial work in AP cell cultures by demonstrating that tsK vectors can also deliver their transgenes to experimental pituitary tumours in vivo and achieve a substantial level of expression in the target cells.

If future studies confirm that HSV-1-derived vectors are also effective at delivering therapeutic genes into primary pituitary tumours, herpetic vectors could become one of the systems of choice for gene therapy approaches to pituitary neoplasms (21). Overall, the present results have implications for basic studies and potential gene therapy approaches to pituitary diseases.

\section{Acknowledgements}

The authors are grateful to Ms Yolanda Sosa and Mónica Carino for technical assistance, to Dr Luzbel de la Sota for assistance with the statistics software and to Ms Grabriela Simonetto for editorial help. R G G and F B are also grateful to Drs Maria G Castro and Pedro R Lowenstein, University of Manchester, UK, for their continued encouragement and support in the field of gene therapy. This work was aided in part by grant No. PIP96 from the Argentine Research Council (CONICET) and grant No. PICT4594 from the National Agency for the Promotion of Science and Technology to R G G. V R is grateful to Province of Buenos Aires Research Council (CIC-PBA) for its continued support. F B is a doctoral fellow and R G G, V R and N G C are senior scientists of CONICET.

\section{References}

1 Bolognani F \& Goya RG. Gene therapy in the neuroendocrine system: its implementation in experimental models using viral vectors. Neuroendocrinology 2001 73 75-83.

2 Castro MG, Goya RG, Sosa YE, Rowe J, Larregina A, Morelli A et al. Expression of trangenes in normal and neoplastic anterior pituitary cells using recombinant adenovirus: long term expression, cell cycle dependency, and effects of hormone secretion. Endocrinology $19971382184-2194$.

3 Goya RG, Rowe J, Sosa YE, Tomasec P, Lowenstein PR \& Castro MG. Use of recombinant herpes simplex virus type I vectors for gene transfer into tumour and normal anterior pituitary cells. Molecular and Cellular Endocrinology 1998139 199-207.

4 Neill JD, Musgrove LC, Duck LW \& Sellers JC. High efficiency method for gene transfer in normal pituitary gonadotropes: adenoviral-mediated expression of $\mathrm{G}$ protein-coupled receptor kinase 2 suppresses luteinizing hormone secretion. Endocrinology $19991402562-2569$.

5 Lee EJ, Anderson LM, Thimmapaya B \& Jameson JL. Targeted expression of toxic genes directed by pituitary hormone promoters: a potential strategy for adenovirus-mediated gene therapy of pituitary tumours. Journal of Clinical Endocrinology and Metabolism 199984 786-794.

6 Windeatt S, Southgate TD, Dewey RA, Bolognani F, Perone MJ, Larregina AT et al. Adenovirus-mediated herpes simplex virus type-1 thymidine kinase gene therapy suppresses oestrogen induced pituitary prolactinomas. Journal of Clinical Endocrinology and Metabolism 200085 1296-1305.

7 Lee EJ, Thimmapaya B \& Jameson JL. Stereotactic injection of adenoviral vectors that target gene expression to specific pituitary cell types: implications for gene therapy. Neurosurgery $2000461461-1469$.

8 Southgate TD, Windeatt S, Smith-Arica J, Gerdes CA, Perone MJ, Morris I et al. Transcriptional targeting to anterior pituitary lactotrophic cells using recombinant adenovirus vectors in vitro and in vivo in normal and estrogen/sulpirideinduced hyperplastic anterior pituitaries. Endocrinology 2000 141 3493-3505.

9 Lowenstein PR, Morrison EE, Bain D, Hodge P, Preston CM, Clissold $\mathrm{P}$ et al. Use of recombinant vectors derived from herpes simplex virus 1 mutant $t s \mathrm{~K}$ for short-term expression of transgenes encoding cytoplasmic and membrane anchored proteins in postmitotic polarized cortical neurons and glial cells in vitro. Neuroscience $1994 \mathbf{6 0} 1059-1077$.

10 Tomasec P, Bain D, Castro MG, Preston CM \& Lowenstein PR. Herpes simplex virus temperature-sensitive mutant tsK as a vector 
for neuronal gene transfer. In Protocols for Gene Transfer in Neuroscience: Towards Gene Therapy of Neurological Disorders, ch 14, pp 169-186. Eds PR Lowenstein \& LW Enquist. Chichester: John Wiley \& Sons, 1996.

11 Tomasec P, Preston CM, Linton EA, Ahmed I, Lowenstein PR \& Castro MG. Generation of a recombinant Herpes simplex virus type 1 expressing the rat corticotropin-releasing hormone precursor: endoproteolytic processing, intracellular targeting and biological activity. Neuroendocrinology 199970 439-450.

12 The Biological Council Animal Research and Welfare Panel. Guidelines on Handling and Training of Laboratory Animals. Wheathampsted, Herts, UK: UFAW, 1992.

13 Paxinos G \& Watson C. The Rat Brain in Stereotaxic Coordinates, edn 2. San Diego, CA: Academic Press, 1986.

14 Roizman B. The function of herpes simplex virus genes: a primer for genetic engineering of novel vectors. PNAS 199693 11307-11312.

15 Wolfe D, Goins WF, Yamada M, Moriuchi S, Krisky DM, Oligino TJ et al. Engineering herpes simplex virus vectors for CNS applications. Experimental Neurology 1999159 34-46.

16 Liu Y, Rabinovitch A, Suarez-Pinzon W, Muhkerjee B, Brownlee M, Edelstein D et al. Expression of the bcl-2 gene from a defective HSV-1 amplicon vector protects pancreatic betacells from apoptosis. Human Gene Therapy 19967 1719-1726.
17 Rabinovitch A, Suarez-Pinzon W, Strynadka K, Ju Q, Edelstein D, Brownlee $\mathrm{M}$ et al. Transfection of human pancreatic islets with an anti-apoptotic gene (bcl-2) protects $\beta$-cells from cytokineinduced destruction. Diabetes 199948 1223-1229.

18 Tomasec P. Expression, post-translational processing, sorting and targeting of corticotrophin-releasing hormone precursor (preproCRH) in neocortical neurons and eukaryotic cells from HSV1 derived vector. $P h D$ Thesis. University of Wales, 1997.

19 Everly DN \& Read GS. Mutational analysis of the virion host shutoff gene (UL41) of herpes simplex virus (HSV): characterization of HSV type 1 (HSV-1)/HSV-2 chimeras. Journal of Virology $1997717157-7166$.

20 Elgadi MM, Hayes CE \& Smiley JR. The herpes simplex virus vhs protein induces endoribonucleolytic cleavage of target RNAs in cell extracts. Journal of Virology 199973 7153-7164.

21 Castro MG. Gene therapy strategies for the treatment of pituitary tumours. Journal of Molecular Endocrinology 199922 9-18.

Received 15 January 2001

Accepted 25 May 2001 